\title{
Impact of Long-Term Green Manuring on Zinc Transformations in Calcareous Soil under Rice-Wheat System
}

\author{
Sunil Kumar* \\ Department of Soil Science and Agricultural Chemistry, Bihar Agricultural University, \\ Sabour, Bhagalpur, Bihar - 813210, India \\ *Corresponding author
}

\section{A B S T R A C T}

A long-term field experiment was carried out with green manuring to see the impact on Zinc transformations in calcareous soil under rice-wheat cropping system. After completion of 5th cycle, Soil samples were collected from each plot and Zinc

\begin{tabular}{|l|}
\hline Key w or d s \\
Green manure, \\
FYM, Zinc \\
fractions, Rice, \\
Wheat and \\
Calcareous soil. \\
\hline Article Info \\
\hline Accepted: \\
26 August 2017 \\
Available Online: \\
10 September 2017 \\
\hline \hline
\end{tabular}
transformation process was executed. The distribution of native and applied $\mathrm{Zn}$ into different fractions indicated that most of the total- $\mathrm{Zn}$ remains in residual form and the quantity in plant usable forms like water soluble + exchangeable, complexed and organic form were very low which were about 0.34 to $0.91,1.00$ to 1.46 and 1.17 to 1.91 per cent, respectively of the total $\mathrm{Zn}$. The order of dominancy of different fractions in soil was : residual $\mathrm{Zn}>$ crystalline sesquioxide $\mathrm{Zn}>$ organically complexed $\mathrm{Zn}>$ inorganically complexed $\mathrm{Zn}>$ amorphous sesquioxide $\mathrm{Zn}>$ water soluble + exchangeable $\mathrm{Zn}$. Mutual transformation of water soluble + exchangeable $\mathrm{Zn}$, organically $\mathrm{Zn}$, crystalline sesquioxide $\mathrm{Zn}$ and residual $\mathrm{Zn}$, seem to be dominant for maintaining $\mathrm{Zn}$ - equilibria in soil. The correlation and multiple regression were very well explained the importance of water soluble + exchangeable, organically complexed $\mathrm{Zn}$ and crystalline sesquioxide bound $\mathrm{Zn}$ in providing sustainable crop production by maintaining $\mathrm{Zn}$-nutrition to crops under ricewheat system. The existence of dynamic equilibria among different $\mathrm{Zn}$-fractions as evident from significant correlation among themselves indicated that there is mutual transformation of $\mathrm{Zn}$ fractions to maintain $\mathrm{Zn}$ equilibria in soil. In conclusions, Dhaincha as well as Green gram plus FYM enhances WSE and ORG-Zn, which are most important for Zn nutrition to Rice-wheat.

\section{Introduction}

Zinc, an essential element in plant growth and metabolism, exists in soil in different forms such as primary and secondary minerals, insoluble inorganic and organic precipitates, soluble organic complexes and exchangeable and adsorbed forms and as soil solution zinc. These forms are in a state of dynamic equilibrium. The amount and rate of transformation of these forms of zinc solution determine the size of the labile $\mathrm{Zn}$ pool.
There are many reports on study of different micronutrient fractions of soils (Viets, 1962; Smith and Shoukry, 1968; Iyengar and Deb, 1977; Raja and Iyenger, 1986; Meki and Olusegun, 2012), but only few studies have been carried out with the application of organic and inorganic fertilizers under ricewheat cropping system in calcareous soils (Prasad et al., 2010; Kamali et al., 2010, 2011; Pandey, 2012). The calcareous soil of 
Bihar occupying a sizeable area is deficient of zinc to the extent of $80-90 \%$ of the tested soil samples and symptoms of zinc deficiency are frequently observed on many crops (Sakal et al., 1996). Widespread occurrence of zinc deficiency in soil suggests that both native and applied forms of $\mathrm{Zn}$ react with the inorganic and organic phase in soil and thereby affect its availability. Zinc diffusion, which is one of the most limiting steps in calcareous soil, is affected by the application of organic materials. Availability of $\mathrm{Zn}$ to plants is influenced by amount of $\mathrm{Zn}$ present in different chemical pools which could be affected by organic matter incorporation. Zinc is known to exist in soil in different chemical pools and its solubility and availability to plant is a function of physical and chemical properties of the soil. Organic amendments such as Green manure, FYM, compost, crop residue, etc. have marked effect on the solubility and availability of different forms of $\mathrm{Zn}$ because of their bio-degradation in soil (Singh et al., 2003; Mishra et al., 2009; Dhaliwal et al., 2010, 2012; Kumar and Kumar, 2012; Kumari and Singh, 2012). The wide scale adoption of rice-wheat system has ushered in an increase in agricultural production, but this intensive system over a period of time and nature of the crops has set declining yield trends as well as deterioration in soil productivity even with optimum use of fertilizers. Hence, for restoration of soil productivity, there is an urgent need to look forward to other options of supplying plant nutrient like Green Manure, FYM, crop residues incorporation. The adverse effect of incorporation of rice and wheat straw can be counteracted by integrating organic amendments with crop residues (Singh et al., 2004). The continuous recycling of crop residue restores the organic matter content and also increases microbial population in the soil (Prasad, 2005). Therefore, for sustained agricultural productivity on a long term basis, proper appraisal of different forms of zinc and their relationships with soil characteristics and $\mathrm{Zn}$ uptake by crops is essential. Hence, the present investigation was carried out to study the effect of green manuring on zinc fractions of calcareous soil and their influences on zinc nutrition.

\section{Materials and Methods}

A long-term field experiment was started in Kharif 2000 in light textured highly calcareous soil at RAU Research farm, Pusa. The experimental soil had $\mathrm{pH} 8.40$, EC 0.32 $\mathrm{dSm}^{-1}$, OC $3.80 \mathrm{~g} \mathrm{~kg}^{-1}$, CEC 8.2 [cmol (p+) $\mathrm{kg}^{-1}$ ], Free $\mathrm{CaCO}_{3} 34.40 \%$ and available $\mathrm{Zn}$ $0.73 \mathrm{mg} \mathrm{kg}^{-1}$. The experiment was laid out in a RBD with following treatment details as $\mathrm{T}_{1}$ control, $\mathrm{T}_{2}$-Sunhemp every year, $\mathrm{T}_{3}$-sunhemp alternate year, $\mathrm{T}_{4}$-Dhaincha every year, $\mathrm{T}_{5^{-}}$ Dhaincha alternate year, $\mathrm{T}_{6^{-}}$Green gram every year, $\mathrm{T}_{7-}$ Green gram $+2.5 \mathrm{t} \mathrm{FYM} \mathrm{ha}^{-1}$ every year, $\mathrm{T}_{8}$-Green gram + 5.0 $\mathrm{t} \mathrm{FYM} \mathrm{ha}^{-1}$ every year, $\mathrm{T}_{9}-10 \mathrm{t}$ FYM ha ${ }^{-1}$ every year and $\mathrm{T}_{10}-10 \mathrm{~kg} \mathrm{Zn} \mathrm{ha}{ }^{-1}$ alternate year. These were mixed thoroughly though out the respective experimental plot one week prior to transplanting of rice. After completion of $5^{\text {th }}$ crop cycle (in 2005), soil samples were collected, processed and fractionation of soil Zinc was done using the method proposed by Iyengar and Deb (1977), modified by Raja and Iyengar (1986). The flow sheet showing the sequential extraction procedure is given in figure 1 .

\section{Total zinc}

A portion of $0.5 \mathrm{~g}$ air dried soil was weighed into a platinum crucible and treated with $5 \mathrm{ml}$ $\mathrm{HNO}_{3}+5 \mathrm{ml} \mathrm{HF}$ and left to stand overnight. Then $2.5 \mathrm{ml} \mathrm{HClO}_{4}$ and 2 drops of $\mathrm{H}_{2} \mathrm{SO}_{4}$ were added. The content was digested and fumed to just moist dryness. After cooling, 5 $\mathrm{ml} \mathrm{HCl}$ was used to dissolve and wash the crucible. After 1 hour, the residue was transferred to $50 \mathrm{ml}$ volumetric flask and 
volume was made-up with distilled water upto the mark. The readings were recorded with the help of Perkin Elemer Atomic Absorption Spectrophotometer. The residual $\mathrm{Zn}$ was determined by subtracting all forms of $\mathrm{Zn}$ extracted from the total $\mathrm{Zn}$ content.

\section{Statistical analysis and presentation of data}

Statistical analysis was done according to the methods outlined by Panse and Sukhatme (1967). The critical difference (CD) at 5 per cent level of probability was worked out for comparing the significant treatment effects. The correlation and multiple regressions were also carried out with the help of computers. The Standard Regression Coefficient (SRC) was worked out as below:

Where,

$\mathrm{SRC}=\mathrm{bi} \sqrt{\frac{\sum \mathrm{x}_{\mathrm{i}}^{2}}{\sum \mathrm{y}_{\mathrm{i}}^{2}}}$

bi $=$ estimated regression coefficient

$\Sigma \mathrm{x}_{\mathrm{i}}^{2}=\Sigma \mathrm{x}_{\mathrm{i}}^{2}-\frac{\left(\Sigma \mathrm{x}_{\mathrm{i}}\right)^{2}}{\mathrm{n}}$

$\mathrm{n}$

$\Sigma \mathrm{y}_{\mathrm{i}}^{2}=\Sigma \mathrm{y}_{\mathrm{i}}^{2}-\stackrel{\left(\Sigma \mathrm{y}_{\mathrm{i}}\right)^{2}}{ }$

n

\section{Results and Discussion}

\section{Distribution of zinc into different fractions}

The data on soil zinc fractions like water soluble plus exchangeable, inorganically complexed, organically bound, amorphous sesquioxide bound, crystalline sesquioxide bound, residual and total zinc as reported in table 1, revealed that content of these fraction in different treatments varied from 0.53 to
$1.55,1.55$ to $2.65,1.82$ to $3.42,1.52$ to 2.17 , 2.20 to $5.13,147.38$ to 176.06 and 155.00 to $188.00 \mathrm{mg} \mathrm{kg}^{-1}$, respectively. It is also clear from the data in table 1 that most of the total $\mathrm{Zn}$ was present in residual form and only small fraction was present in easily available form. It was observed that green manure and FYM application increased all the fractions of $\mathrm{Zn}$ except amorphous fraction. It is also clear from the data that most of the $\mathrm{Zn}$ recycled through green manuring as well as application of FYM alone or in conjunction with green manure got accumulated in residual as well as organic fraction. It was conspicuous from the data in table 2 that more than 95 per cent of the total native zinc existed in residual fraction. However, an application of $\mathrm{Zn}$ either through inorganic fertilizer or recycled with organic sources, there was reduction in the quantity of this fraction. The reduction was more pronounced when $\mathrm{Zn}$ was applied through FYM. Green manuring and FYM application increase the organic fraction of $\mathrm{Zn}$ from 1.17 to 1.91 per cent while this change in water soluble plus exchangeable fraction was from 0.34 to 0.70 per cent. The distribution of other $\mathrm{Zn}$ fractions in native or applied $\mathrm{Zn}$ varied from 1.00 to 1.46 per cent (complexed form), 0.53 to 1.27 per cent (amorphous form) and 1.42 to 3.00 per cent in crystalline form. The distribution of native and applied $\mathrm{Zn}$ into the form held by water soluble plus exchangeable $\mathrm{Zn}$ was much less than that held by crystalline $\mathrm{Fe}$ and $\mathrm{Al}$ oxide. Although, the per cent of total $\mathrm{Zn}$ in organically complexed form was found next to crystalline $\mathrm{Fe}$ and $\mathrm{Al}$ oxide bound form but the transformation of applied $\mathrm{Zn}$ was meagre. The distribution of total $\mathrm{Zn}$ into residual fraction was also reported to be more than 90 per cent (Mandal and Mandal, 1986). However, other worker like Singh et al., (1987) and Spalbar et al., (2017) reported 75 90 per cent of total $\mathrm{Zn}$ in the form of residual fraction. Mandal and Mandal (1986) also reported that a small fraction viz., 0.26, 0.74, 
1.58 and 0.71 per cent of the total $\mathrm{Zn}$ occured as water soluble + exchangeable, organic complexed, amorphous sesquioxide and crystalline sesquioxide bound forms. High content of $\mathrm{Zn}$ as organic fraction in the present investigation might be due high organic carbon build up in soil due to green manuring and FYM additions. The order of dominance of different $\mathrm{Zn}$ fractions in soil was Residual $\mathrm{Zn}>$ crystalline sesquioxide bound- $\mathrm{Zn}>$ Organically bound-Zn > Inroganic complexed $\mathrm{Zn}>$ Amorphous sesquioxide bound $\mathrm{Zn}>$ water soluble + exchangeable $\mathrm{Zn}$.

\section{Relationship among different zinc fractions}

The data on correlation coefficient value among different $\mathrm{Zn}$ fractions (Table 3) revealed that dynamic equilibrium of zinc existed between water soluble plus exchangeable, inorganic complexed, organically complexed, crystalline sesquioxide bound and residual forms as positive and highly significant correlation coefficient values were noted among these fractions. Zinc in amorphous sesquioxide bound failed to produce significant correlation with any fraction of $\mathrm{Zn}$ except organically complexed $\mathrm{Zn}(\mathrm{r}=-0.711 *)$. Existence of dynamic equilibrium among all these fracttions have been reported by many workers like Hazra et al., (1987), Chowdhary et al., (1997), Sharad and Verma (2001), Begum et al., (2016) and Okoli et al., (2016). This suggested that mutual transformation of water soluble plus exchangeable $\mathrm{Zn}$, inorganically complexed $\mathrm{Zn}$, organically complexed Zn, crystalline sesquioxide bound $\mathrm{Zn}$ and residual $\mathrm{Zn}$ seems to be dominant for maintaining $\mathrm{Zn}$ equilibria in soil during absorption of $\mathrm{Zn}$ by crops. The mutual significant correlation among different fractions also helps in maintaining quick equilibria and replenishing the available fractions in soil to meet the crop requirement.

\section{Relationship of $\mathrm{Zn}$ fractions with plant and soil parameters}

The correlation studies were carried out for plant parameters like grain yield of rice and wheat, total $\mathrm{Zn}$ uptake by rice and wheat and available $\mathrm{Zn}$ and organic carbon in soil with different $\mathrm{Zn}$ fractions and the correlation coefficient value ( $r$ ) are presented in table 4 . It was noticed that all the $\mathrm{Zn}$ fractions except amorphous sesquioxide boun-Zn, were significantly and positively correlated with all the plant parameters tested except grain yield of wheat which produce significant and positive correlation only with organic $\mathrm{Zn}(\mathrm{r}=$ $0.714 * *)$. It is also conspicuous from the data that organically complexed fraction of $\mathrm{Zn}$ was significantly and positively correlated with all the plant parameters. Among different fractions, water soluble plus exchangeable fraction produced highest correlation coefficient values with all the plant and soil parameters tested showing its highest importance in maintaining $\mathrm{Zn}$ nutrition to rice-wheat system. The importance of exchangeable and organically bound $\mathrm{Zn}$ with respect to $\mathrm{Zn}$ nutrition of rice and wheat has also been demonstrated by Sharad and Verma (2001), Umesh et al., (2013) and Kumari et al.,.(2015) Contribution of these two fractions in DTPA extractable $\mathrm{Zn}$ has been shown by above workers. In the present study significant correlation of available $\mathrm{Zn}$ with water soluble + exchangeable, inorganically complexed and crystalline sesquioxide bound form demonstrated that DTPA-Zn was able to extract $\mathrm{Zn}$ from these fractions. Highest correlation coefficient value of organic bound-Zn was noted with organic carbon showing the importance of green manuring in $\mathrm{Zn}$ nutrition of crops.

The relative contribution of soil $\mathrm{Zn}$ fractions towards plant parameters as well as available $\mathrm{Zn}$ was tried to be studied through multiple regression analysis. 
Fig.1 Flow sheet showing the scheme adopted for sequential fractionation of soil Zinc

Dry soil $(5 g)$

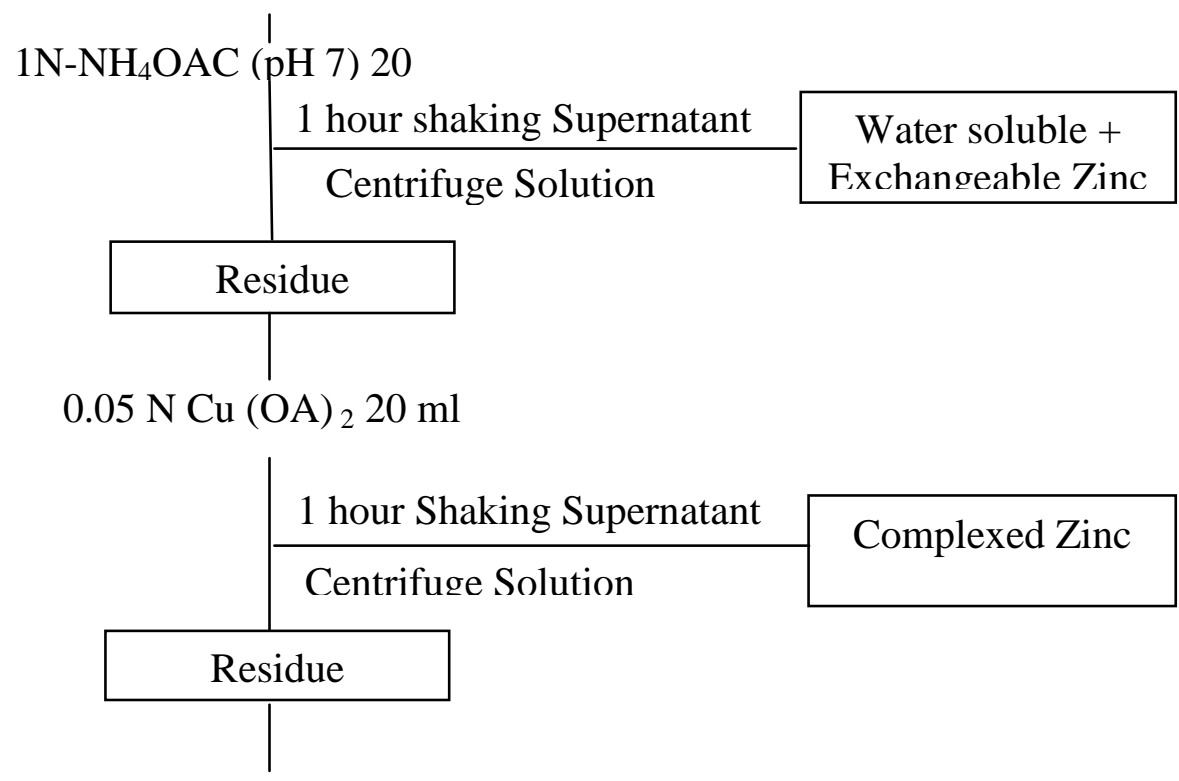

$1 \%$ Sod Pyrophosphate $(20 \mathrm{ml})$

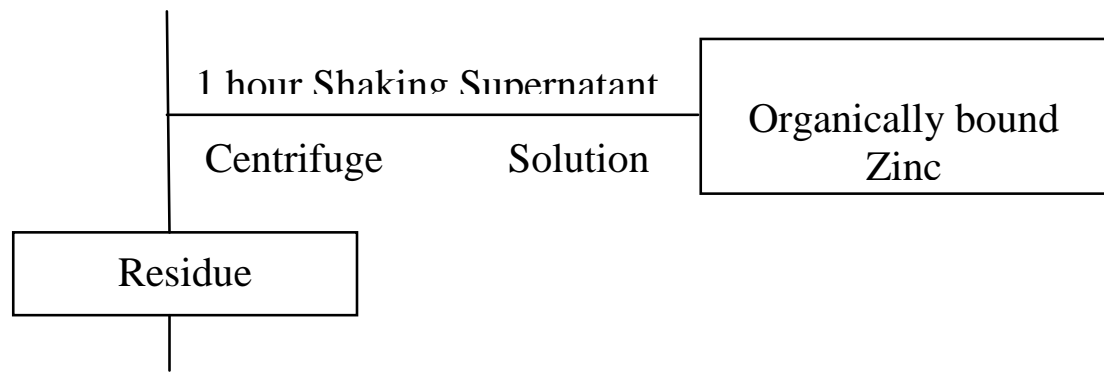

$0.1 \mathrm{M} \mathrm{HCl}(20 \mathrm{ml})$

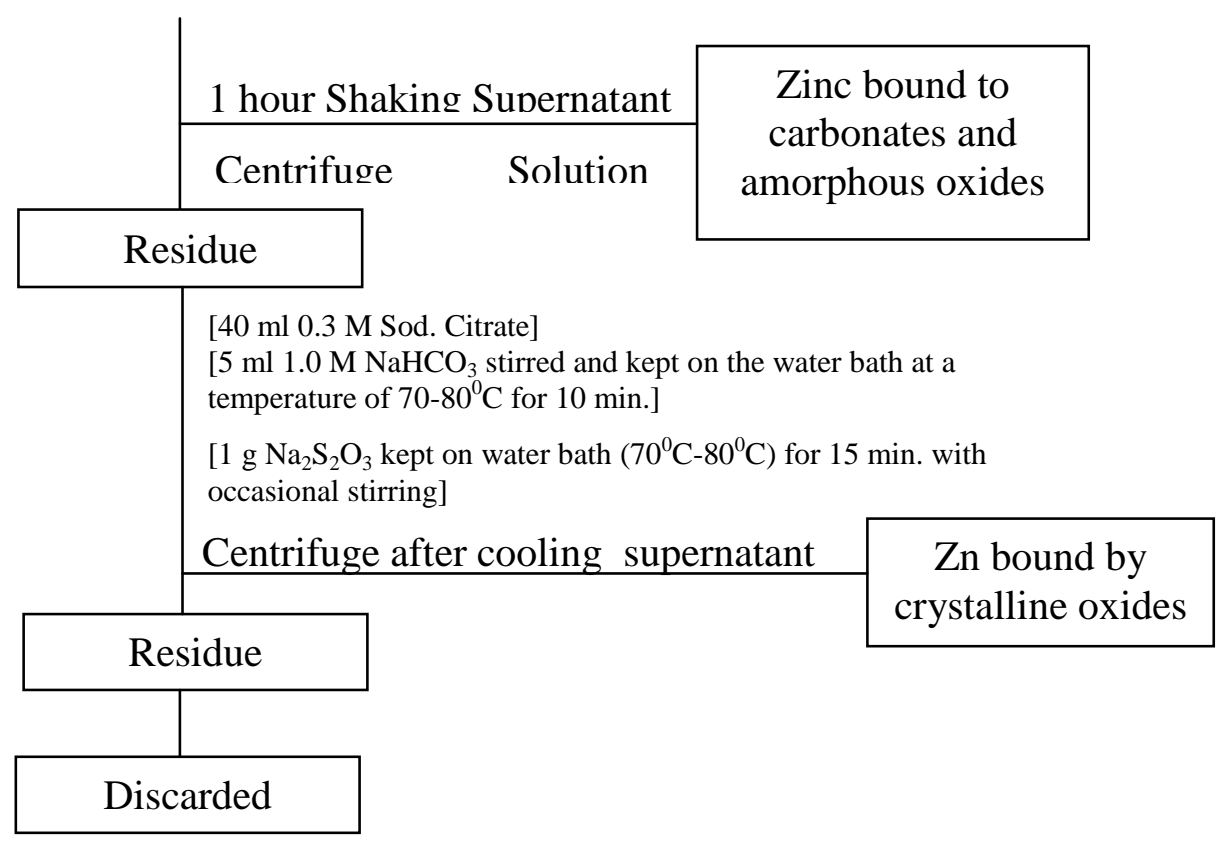


Table.1 Distribution of $\mathrm{Zn}$ in different fractions $\left(\mathrm{mg} \mathrm{kg}^{-1}\right)$ in post-harvest soil of wheat $\left(10^{\text {th }} \mathrm{crop}\right)$ as Influenced by green manuring under rice-wheat system

\begin{tabular}{|c|c|c|c|c|c|c|c|}
\hline \multirow{2}{*}{ Treatments } & \multicolumn{7}{|c|}{ Different fractions of Zinc } \\
\hline & WSE & COM & ORG & AMO & CRY & RES-Zn & Total-Zn \\
\hline $\mathrm{T}_{1}-$ Control & 0.53 & 1.55 & 1.62 & 1.52 & 2.20 & 147.38 & 155.00 \\
\hline $\mathrm{T}_{2}-$ Sunhemp (every year) & 0.76 & 1.99 & 2.50 & 1.12 & 3.15 & 157.48 & 167.00 \\
\hline $\mathrm{T}_{3}-$ Sunhemp (alternate year) & 0.67 & 1.69 & 2.18 & 1.74 & 2.76 & 152.97 & 162.00 \\
\hline $\mathrm{T}_{4}-$ Dhaincha (every year) & 1.03 & 2.04 & 3.30 & 1.08 & 3.57 & 161.98 & 173.00 \\
\hline $\mathrm{T}_{5}-$ Dhaincha (alternate year) & 0.67 & 1.86 & 2.32 & 1.28 & 2.70 & 156.17 & 165.00 \\
\hline $\mathrm{T}_{6}-$ Green gram (every year) & 0.64 & 2.08 & 2.08 & 2.00 & 3.06 & 152.14 & 162.00 \\
\hline $\mathrm{T}_{7}-$ Green gram $+2.5 \mathrm{t} \mathrm{FYM} \mathrm{ha}{ }^{-1}$ (every year) & 0.83 & 2.12 & 2.38 & 1.62 & 3.07 & 155.98 & 166.00 \\
\hline $\mathrm{T}_{8}-$ Green gram $+5 \mathrm{t} \mathrm{FYM} \mathrm{ha}{ }^{-1}$ (every year) & 1.27 & 2.65 & 3.34 & 1.04 & 4.20 & 168.51 & 181.00 \\
\hline $\mathrm{T}_{9}-10.0 \mathrm{t} \mathrm{FYM} \mathrm{ha}^{-1}$ (every year) & 1.21 & 2.51 & 3.42 & 1.00 & 3.80 & 176.06 & 188.00 \\
\hline $\mathrm{T}_{10}-10 \mathrm{~kg} \mathrm{Zn} \mathrm{ha}^{-1}$ (alternate year) & 1.55 & 2.41 & 2.21 & 2.17 & 5.13 & 157.54 & 171.00 \\
\hline Mean & 0.92 & 2.09 & 2.54 & 1.46 & 3.34 & 158.67 & 169.00 \\
\hline S.Em. \pm & 0.032 & 0.051 & 0.104 & 0.061 & 0.158 & 7.466 & 4.496 \\
\hline $\mathrm{CD}(0.0 \overline{5})$ & 0.094 & 0.152 & 0.308 & 0.179 & 0.468 & $\mathrm{NS}$ & 13.357 \\
\hline
\end{tabular}

WSE: -Water soluble + Exchangeable, COM: - Inorganically complexed, ORG: - Organically complexed, AMO: - Amorphous sesquioxide, CRY: - crystalline sesquioxide, RES: - Residual zinc

Total.2 Effect of green manuring on per cent (\%) contribution of different fractions towards total zinc in post-harvest soil

\begin{tabular}{|c|c|c|c|c|c|c|}
\hline \multirow[t]{2}{*}{ Treatments } & \multicolumn{6}{|c|}{ Different fractions of Zinc } \\
\hline & WSE & COM & ORG & AMO & CRY & RES \\
\hline $\mathrm{T}_{1}-$ Control & 0.34 & 1.00 & 1.17 & 0.98 & 1.42 & 95.08 \\
\hline $\mathrm{T}_{2}-$ Sunhemp (every year) & 0.46 & 1.19 & 1.50 & 0.67 & 1.89 & 94.30 \\
\hline $\mathrm{T}_{3}-$ Sunhemp (alternate year) & 0.41 & 1.04 & 1.35 & 1.07 & 1.70 & 94.43 \\
\hline $\mathrm{T}_{4}-$ Dhaincha (every year) & 0.60 & 1.18 & 1.91 & 0.62 & 2.06 & 93.63 \\
\hline $\mathrm{T}_{5}-$ Dhaincha (alternate year) & 0.41 & 1.13 & 1.41 & 0.78 & 1.64 & 94.65 \\
\hline $\mathrm{T}_{6}-$ Green gram (every year) & 0.40 & 1.28 & 1.28 & 1.23 & 1.89 & 93.91 \\
\hline $\mathrm{T}_{7}-$ Green gram $+2.5 \mathrm{t}$ FYM ha ${ }^{-1}$ (every year) & 0.50 & 1.28 & 1.43 & 0.98 & 1.85 & 93.96 \\
\hline $\mathrm{T}_{8}-$ Green gram $+5 \mathrm{t} \mathrm{FYM} \mathrm{ha}^{-1}$ (every year) & 0.70 & 1.46 & 1.85 & 0.57 & 2.32 & 93.10 \\
\hline $\mathrm{T}_{9}-10.0 \mathrm{t} \mathrm{FYM} \mathrm{ha}^{-1}$ (every year) & 0.64 & 1.34 & 1.82 & 0.53 & 2.02 & 93.65 \\
\hline $\mathrm{T}_{10}-10 \mathrm{~kg} \mathrm{Zn} \mathrm{ha}^{-1}$ (alternate year) & 0.91 & 1.41 & 1.29 & 1.27 & 3.00 & 92.13 \\
\hline Mean & 0.54 & 1.2 & 1.49 & 0.87 & 1.96 & 93.11 \\
\hline
\end{tabular}

WSE:-Water soluble + Exchangeable, COM:- Inorganically complexed, ORG:- Organically complexed, AMO:- Amorphous sesquioxide, CRY:- crystalline sesquioxide, RES:- Residual zinc 
Table.3 Correlation coefficient among different soil Zinc fractions

\begin{tabular}{|c|c|c|c|c|c|}
\hline & $\begin{array}{l}\text { Inorganically } \\
\text { complexed-Zn }\end{array}$ & $\begin{array}{c}\text { Organically } \\
\text { complexed-Zn }\end{array}$ & $\begin{array}{c}\text { Amorphous } \\
\text { sesquioxide-Zn }\end{array}$ & $\begin{array}{c}\text { Crystalline } \\
\text { sesquioxide-Zn }\end{array}$ & Residual- Zn \\
\hline Water soluble + Exchangeable $-\mathrm{Zn}$ & $0.850 * *$ & 0.579 & -0.027 & $0.963 * *$ & $0.670^{*}$ \\
\hline Inorganically complexed-Zn & & $0.708^{*}$ & -0.190 & $0.850 * *$ & $0.805^{* *}$ \\
\hline Organically complexed-Zn & & & $-0.711 *$ & 0.510 & $0.923 * *$ \\
\hline Amorphous sesquioxide-Zn & & & & 0.105 & -0.624 \\
\hline Crystalline sesquioxide-Zn & & & & & 0.574 \\
\hline
\end{tabular}

$*=$ significant at 0.05 level, $* *=$ significant at 0.01 level

Table.4 Correlation coefficient between plant and soil parameters Vs Zinc fractions in soil

\begin{tabular}{|c|c|c|c|c|c|c|}
\hline \multirow[t]{2}{*}{ Plant/soil parameters } & \multicolumn{6}{|c|}{ Different fractions of Zinc } \\
\hline & WSE & COM & ORG & AMO & CRY & RES \\
\hline Grain yield of Rice & $0.782 * *$ & $0.860 * *$ & $0.804 * *$ & -0.359 & $0.752^{*}$ & $0.784 * *$ \\
\hline Grain yield of wheat & 0.621 & 0.494 & $0.714 *$ & -0.478 & 0.602 & 0.619 \\
\hline Zinc uptake by rice & $0.943 * *$ & $0.887 * *$ & $0.679 *$ & -0.137 & $0.924 * *$ & $0.726 *$ \\
\hline Zinc uptake by wheat & $0.930 * *$ & $0.850 * *$ & $0.704 *$ & -0.204 & $0.900 * *$ & $0.719 *$ \\
\hline Available Zinc & $0.946 * *$ & $0.770 * *$ & 0.396 & 0.145 & $0.956 * *$ & 0.497 \\
\hline Organic carbon & 0.558 & $0.711 *$ & $0.970 * *$ & $-0.778 * *$ & 0.483 & $0.931 * *$ \\
\hline
\end{tabular}

$*=$ significant at 0.05 level, $* *=$ significant at 0.01 level

WSE:-Water soluble + Exchangeable, COM:- Inorganically complexed, ORG:- Organically complexed, AMO:- Amorphous sesquioxide, CRY:- crystalline sesquioxide, RES:- Residual zinc 
Table.5 Step down multiple regression showing influence of Zinc pools on plant parameters and available zinc of soil

\begin{tabular}{|c|c|c|c|c|}
\hline $\begin{array}{l}\text { S. } \\
\text { No. }\end{array}$ & Y Factor & Regression analysis & $\mathbf{R}^{2}$ & $\mathbf{R}^{2}(\mathbf{a d j})$ \\
\hline \multirow[t]{6}{*}{1.} & \multirow[t]{6}{*}{$\begin{array}{l}\text { Grain yield of } \\
\text { rice }\left(\mathrm{Y}_{1}\right)\end{array}$} & $\begin{array}{l}\text { a. } 50.28+4.86(0.54) \mathrm{WSE}+5.82(0.67) \mathrm{COM}+3.93(0.80) \mathrm{ORG}-0.07(-0.01) \\
\text { AMO }-0.86(-0.25) \mathrm{CRY}-0.22(-0.72) \text { Total Zn. }\end{array}$ & 0.854 & 0.561 \\
\hline & & $\begin{array}{l}\text { b. } 50.13+4.91(0.54) \text { WSE + } 5.81(0.67) \mathrm{COM}+3.97(0.80) \mathrm{ORG}-0.89(-0.26) \\
\text { CRY }-0.22(-0.72) \text { Total Zn. }\end{array}$ & 0.854 & 0.671 \\
\hline & & $\begin{array}{l}\text { c. } 44.85+2.72(0.30) \mathrm{WSE}+4.97(0.58) \mathrm{COM}+3.78(0.76) \mathrm{ORG}-0.18(-0.60) \\
\text { Total } \mathrm{Zn} .\end{array}$ & $0.851 *$ & 0.731 \\
\hline & & d. $22.15+2.01(0.22) \mathrm{WSE}+3.30(0.38) \mathrm{COM}+2.00(0.40) \mathrm{ORG}$ & $0.828^{*}$ & 0.742 \\
\hline & & e. $20.59+5.00 *(0.58) \mathrm{COM}+1.95(0.39) \mathrm{ORG}$ & $0.814 * *$ & 0.761 \\
\hline & & f. $\quad 20.51+7.39 * *(0.86) \mathrm{COM}$ & $0.737 * *$ & 0.704 \\
\hline \multirow[t]{4}{*}{2.} & \multirow[t]{4}{*}{$\begin{array}{l}\text { Grain yield of } \\
\text { wheat (Y2) }\end{array}$} & $\begin{array}{l}\text { a. } 38.80-2.13(-0.56) \mathrm{WSE}-3.47(-0.96) \mathrm{COM}+0.49(0.24) \mathrm{ORG}-2.03(-0.67) \\
\mathrm{AMO}+2.67(1.87) \mathrm{CRY}+0.01(0.06) \text { Total } \mathrm{Zn} .\end{array}$ & 0.829 & 0.487 \\
\hline & & $\begin{array}{l}\text { b. } 39.81-1.99(-0.53) \mathrm{WSE}-3.38(-0.94) \mathrm{COM}+0.56(0.27) \mathrm{ORG}-2.03(-0.67) \\
\mathrm{AMO}+2.62(1.84) \mathrm{CRY}\end{array}$ & 0.829 & 0.615 \\
\hline & & $\begin{array}{l}\text { c. } 40.99-2.17(-0.57) \mathrm{WSE}-3.09(-0.86) \mathrm{COM}-2.61 *(-0.86) \mathrm{AMO}+2.82(1.97) \\
\text { CRY }\end{array}$ & $0.820^{*}$ & 0.675 \\
\hline & & d. $41.29-3.05(-0.84) \mathrm{COM}-2.37(-0.78) \mathrm{AMO}+2.00 *(1.40) \mathrm{CRY}$ & $0.801 *$ & 0.702 \\
\hline \multirow[t]{6}{*}{3.} & \multirow[t]{6}{*}{$\begin{array}{l}\text { Zinc uptake by } \\
\text { rice (Y3) }\end{array}$} & $\begin{array}{l}\text { a. } 178.73+96.00(0.56) \mathrm{WSE}+38.10(0.23) \mathrm{COM}+25.44(0.27) \mathrm{ORG}-2.46(- \\
\text { 0.02) } \mathrm{AMO}+12.86(0.20) \mathrm{CRY}-1.24(-0.21) \text { Total Zn. }\end{array}$ & 0.931 & 0.793 \\
\hline & & $\begin{array}{l}\text { b. } 173.48+97.79(0.57) \mathrm{WSE}+37.95(0.23) \mathrm{COM}+27.05(0.29) \mathrm{ORG}+11.52 \\
(0.18) \mathrm{CRY}-1.24(-0.21) \text { Total Zn. }\end{array}$ & $0.931 *$ & 0.845 \\
\hline & & $\begin{array}{l}\text { c. } 241.63+125.96 * *(0.73) \mathrm{WSE}+48.87(0.30) \mathrm{COM}+29.44(0.30) \mathrm{ORG}-1.74 \\
(-0.29) \text { Total } \mathrm{Zn} .\end{array}$ & $0.930 * *$ & 0.873 \\
\hline & & d. $28.89+119.25^{*}(0.69) \mathrm{WSE}+33.27(0.20) \mathrm{COM}+12.70(0.13) \mathrm{ORG}$ & $0.924 * *$ & 0.886 \\
\hline & & e. $61.46+142.41 * *(0.83) \mathrm{WSE}+18.92(0.20) \mathrm{ORG}$ & $0.915^{* *}$ & 0.891 \\
\hline & & f. $\quad 91.06+162.45^{* *}(0.94) \mathrm{WSE}$ & $0.890 * *$ & $\begin{array}{c}0.875 \\
\text { Contd... }\end{array}$ \\
\hline
\end{tabular}


4. Zinc uptake by wheat $\left(\mathrm{Y}_{4}\right)$

5. Available Zinc $\left(\mathrm{Y}_{5}\right)$ a.

$340.67+77.24(0.74) \mathrm{WSE}+17.89(0.18) \mathrm{COM}+23.16(0.39) \mathrm{ORG}-12.32(-0.14)$

0.924

0.771 $\mathrm{AMO}+7.88(0.20) \mathrm{CRY}-1.76(-0.48)$ Total Zn.

b. $\quad 368.40+94.44 *(0.88) \mathrm{WSE}+23.34(0.23) \mathrm{COM}+26.73(0.46) \mathrm{ORG}-8.76(-0.10)$ AMO - $2.01(-0.54)$ Total Zn.

c. $321.90+89$ Total Zn.

d. $\quad 272.04+96.92 * *(0.90) \mathrm{WSE}+29.07(0.50) \mathrm{ORG}-1.28(-0.35)$ Total Zn.

$0.915^{* *}$ 0.872

e. $\quad 104.76+84.04 * *(0.78) \mathrm{WSE}+14.65(0.25) \mathrm{ORG}$

$0.905 * * \quad 0.877$

f. $\quad 127.69+99.56 * *(0.9)$ WSE

a.

$0.44+0.19(0.46)$

$+0.11(0.71) \mathrm{CRY}+0.001(0.07)$ Total Zn.

c. $\quad 0.56+0.21(0.50)$

d. $\quad 0.47+0.24(0.58) \mathrm{WSE}-0.04(-0.19) \mathrm{ORG}+0.08(0.49) \mathrm{CRY}$

$0.946 * * \quad 0.919$

e. $\quad 0.56+0.44 * *(1.08) \mathrm{WSE}-0.05(-0.23) \mathrm{ORG}$

0.909 
Stepwise multiple regression equation of grain yield of rice $\left(\mathrm{Y}_{1}\right)$, grain yield of wheat $\left(\mathrm{Y}_{2}\right)$, total $\mathrm{Zn}$ uptake by rice $\left(\mathrm{Y}_{3}\right)$, total $\mathrm{Zn}$ uptake by wheat $\left(\mathrm{Y}_{4}\right)$ and available $\mathrm{Zn}$ in post-harvest soil $\left(\mathrm{Y}_{5}\right)$ as $\mathrm{Y}$ factors were worked out taking different fractions of $\mathrm{Zn}$ like water soluble + exchangeable (WSE) inorganically complexed (COM), organically complexed (ORG) amorphous sesquioxide bound (AMO), crystalline sesquioxide bound (CRY), residual $\mathrm{Zn}$ (RES) and total $\mathrm{Zn}$ as $\mathrm{X}$ factors and presented in table 5. Step-down multiple regression equation for grain yield of rice could significantly be explained through variations in $\mathrm{COM}$ and $\mathrm{ORG} \mathrm{Zn}$. The individual effect of inorganically complexed (COM) $\mathrm{Zn}$ was significant and positive. Inclusion of other fractions like, residual, water soluble + exchangeable, amorphous sesquioxide and total $\mathrm{Zn}$ explained additional 4.0 per cent variation in grain yield of rice. The standard regression coefficient as given in parentheses indicated that inorganically complexed (COM) Zn was most important $\mathrm{Zn}$ fractions, as compared to organically complexed (ORG) Zn and other Zn fractions.

The extent of variation in grain yield of wheat which could be explained through the variation in inorganically complexed (COM), amorphous sesquioxide bound (AMO) and crystalline sesquioxide bound $\mathrm{Zn}$ (equation' $\mathrm{d}$ ' of $\mathrm{Y}_{2}$ ) was found to be 80.1 per cent with significant effect of amorphous and crystalline sesquioxide bound $\mathrm{Zn}$ fractions. Addition of other $\mathrm{Zn}$ fractions like residual Zn, water soluble + exchangeable, organically complexed and total- $\mathrm{Zn}$ in the step-wise regression equation (equation $\mathrm{d}$ of $\mathrm{Y}_{2}$ ) hardly explained up-to 2.8 per cent additional variation in grain yield of wheat. On comparing standard regression coefficient, the relative importance among $\mathrm{Zn}$ fractions was more for crystalline sesquioxide bound $\mathrm{Zn}$ followed by amorphous sesquiioxide bound $\mathrm{Zn}$ in explaining the variation in grain yield of wheat.
The importance of $\mathrm{Zn}$ fractions like water soluble + exchangeable and organically bound $\mathrm{Zn}$ has been shown through multiple regression equation ('e' of $\mathrm{Y}_{3}$ ) where 91.5 per cent variations in total $\mathrm{Zn}$ uptake by rice crop was explained through variations in these fractions. Further inclusion of other fractions in the regression equation hardly explained 1.6 per cent additional variation in total $\mathrm{Zn}$ uptake by rice. From equation 'e' water soluble + exchangeable $\mathrm{Zn}$ emerged as the most important $\mathrm{Zn}$ fraction followed by organically bound $\mathrm{Zn}$ fraction as reflected by their standard regression coefficient values.

As high as 90.5 per cent variations in total $\mathrm{Zn}$ uptake by wheat could significantly be explained through the variation in water soluble + exchangeable and organically bound $\mathrm{Zn}$ as evident from equation (e of $\mathrm{Y}_{4}$ ). Further inclusion of other four fractions hardly explained any discernible change in total $\mathrm{Zn}$ uptake by wheat. However, exclusion of organically bound fraction in the regression equation ( $\mathrm{f}$ of $\mathrm{Y}_{4}$ ), depleted the extent of variation to be explained was to the extent of 4.2 per cent. The individual effect of water soluble and exchangeable $\mathrm{Zn}$ fraction was highly significant and positive as well as also gave higher standard regression coefficient values denoting importance with respect to total $\mathrm{Zn}$ uptake by wheat.

With regards to available $\mathrm{Zn}$ content in postharvest soil, as high as 94.6 per cent variation (equation ' $d$ ' of $Y_{5}$ ) could significantly be explained through the variations in water soluble + exchangeable $\mathrm{Zn}$, organic complexed $\mathrm{Zn}$ and crystalline sesquioxide bound $\mathrm{Zn}$. However, the individual effect of these three fractions was non-significant. Further, inclusion of other $\mathrm{Zn}$ fractions was able to explain only 0.4 per cent additional variations whereas deletion of crystalline bound and organically bound $\mathrm{Zn}$ fraction from the regression equation failed to explained about 1.7 and 5.1 per cent, 
additional variations, respectively. Comparing the standard regression coefficient in (equation ' $d$ ' of $\mathrm{Y}_{5}$ ), it appears that water soluble + exchangeable $\mathrm{Zn}$ followed by crystalline sesquioxide $\mathrm{Zn}$ was more responsible for variation in available $\mathrm{Zn}$ content of soil.

From the foregoing multiple regression studies, it appears that water soluble $\mathrm{Zn}$ fraction followed by organically bound-Zn played key role in explaining the variations in yield and $\mathrm{Zn}$-uptake by crops under ricewheat system. The available $\mathrm{Zn}$ in postharvest soil appears to be controlled by the above two fractions. However, the contribution of crystalline form of $\mathrm{Zn}$ cannot be ignored in maintaining $\mathrm{Zn}$ nutrition to crops under rice-wheat system. It may be inferred from the result that green manuring played a vital role in $\mathrm{Zn}$ nutrition by maintaining $\mathrm{Zn}$ equilibria in soil. The results regarding relationship between soil $\mathrm{Zn}$ fractions and plant parameters are in conformity with the findings of Chawdhary et al., (1997), Sharad and Verma (2001) and Kumari et al., (2015).

The different fractions of soil $\mathrm{Zn}$ are in dynamic equilibrium with each other and their availability to growing crop depends on their intensities and soil condition. This implies that depleted levels of readily available $\mathrm{Zn}$ in soil could be replenished by other pools of soil $\mathrm{Zn}$. Among different $\mathrm{Zn}$ fractions, $\mathrm{Zn}$ bound to crystalline oxide, followed by $\mathrm{Zn}$ bound to carbonate and amorphous oxide played key role in explaining the variation in yield and Zn uptake by rice and wheat.

\section{Acknowledgements}

The authors are thankful to the sir Dr. A. P. Singh, former Professor, Department of Soil Scienc, RAU, Pusa for their guidance and suggestions during course of investigation and also RAU, Pusa for providing financial assistance. (This manuscript has BAU communication no.300/2017)

\section{References}

Begum, K., Hossain F. and Parveen Z. 2016 Distribution of zinc fractions in relation to properties of some soils of Bangladesh. Dhaka Univ. J. Biol. Sci. 25(1): 19- 25, 2016

Choudhury, A.K., Mclaren, R.G., Cameron, K.C. and Swift, R.S. 1997. Fractionation of zinc in some Newzealand Soils. Communication in Soil Science and Plant Analysis, 28 (35): 301-312.

Dhaliwal, S. S., Sadana, U. S., Hari Ram and Singh, G. 2012. Different fractions of zinc in soil as influenced by manures and fertilizers in long term rice-wheat cropping system in north-west India, $J$. Soils and Crops 22: 226-32.

Dhaliwal, S. S., Sadana, U. S., Sidhu, S. S., Walia, S. S., Dhadli, H. S. and Watts, V. D. 2010. Sequential extraction and chemical fractions of $\mathrm{Zn}$ and $\mathrm{Cu}$ as influenced by manures and fertilizers under long term rice-wheat cropping system in north-west India. Environ, and Ecol., 28: 2600-08.

Hazra, G.C., Mandal, B. and Mandal, L.N. 1987. Distribution of Zinc fractions and their transformation in submerged rice soils. Plant and Soils, 104: 175-181.

Iyengar, B.R.V., and Deb, D.L. 1977. Contribution of Soil Zinc fractions to plant uptake and fate of zinc applied to the soil. Journal of the Indian Society of Soil Science, 25 (3): 426-432.

Kamali, S., Ronaghi, A. and Karimian, N. 2010. Zinc transformation in calcareous soil as affected by applied zinc sulfate, vermicompost and incubation time. Comm. Soil Sci. Plant Analy, 41: 231829. 
Kamali, S., Ronaghi, A. and Karimian, N. 2011. Soil zinc transformations as affected by applied zinc and organic materials. Comm. Soil Sci. Plant Analy, 42: 1038-1049.

Kumar, A., and Kumar, N. 2012.Crop residue management for sustainable crop production and soil health in rice-wheat cropping system. Res. on Crops, 13: 412-17.

Kumari, K., Prasad J, Kumar V. and Solanki I. S. 2015. Effect of crop residue and residual zinc on zinc fractions and their contribution to zinc uptake under ricewheat cropping system in calciorthents. Res. on Crops 16 (2): 205-212.

Kumari, R., and Singh, A. P. 2012. Effect of zinc and crop residue management on fractions for different pools of zinc in an alluvial soil. Environ. And Ecol., 30: 1485-87.

Mandal, L.N., and Mandal, B. 1986. Zinc fractions in soils in relation to zinc nutrition of lowland rice. Soil Science, 142 (3): 141-48.

Meki, C., and Olusegun, A. Y. 2012. The distribution of Zinc fractions in surface samples of selected agricultural soils of Zambia. International Journal of Soil Science, 7 (2): 51-60.

Mishra, P., Singh, R., Srivastava, P. C. and Ram, B. 2009. Effect of continuous cropping and fertilization on zinc fractions and their contribution to plant uptake under rice-wheat system. $J$. Indian Soc. Soil Sci. 57:167-72.

Okoli, N.H., Uzoho B.U., Onweremadu E.U., Nkwopara U.N. and Irokwe I.F. 2016 Zinc Fractionation of Soils of Different Parent Materials and their Relationships with Some Soil Properties. Malaysian Journal of Soil Science. 20: 49-66

Pandey, A. K., 2012. Long term effect of organic and inorganic fertilizers on the distribution and transformation of $\mathrm{S}, \mathrm{Zn}$ and B in calcareous soil. Ph. D. thesis,
Department of Soil Science, RAU, Pusa (Bihar). pp. 200.

Panse, V.G., and Sukhatme, P.V. 1967. Statistical methods for agricultural workers $\left(2^{\text {nd }}\right.$ Ed.) ICAR, New Delhi, Pub.

Prasad, R. K., 2005. Studies on microbial activities and micronutrients availability in a long term experiment on crop residue and zinc application under ricewheat system. M. Sc. thesis, R. A. U., Pusa (Bihar). pp. 87.

Prasad, R. K., Kumar, V., Prasad, B. and Singh, A.P. 2010. Long term effect of crop residues and zinc fertilizer on crop yield, nutrient uptake and fertility buildup under ricewheat cropping system in calciorthents. J. Indian Soc. Soil Sci. 58: 205-211.

Raja, M., Edward and Iyengar, B. R. V. 1986. Chemical pools of zinc in some soils as influenced by sources of applied zinc. $J$. Indian Soc. Soil Sci. 34: 97-105.

Sakal, R., Singh, A. P., Sinha, R. B. and Bhagal, N.S. 1996. Research Bulletin. Department of Soil Science, R. A. U., Pusa (Bihar).

Sharad, N., and Verma, T. S. 2001.Improvement in soil productivity with long term Lantana (Lantana camara L.) addition in rice-wheat cropping-I. Effect on some soil properties and zinc fractions. J. Indian Soc. Soil Sci., 49 (3): 462-466.

Singh, A. P., Sakal, R., Pandeya, S. B., Sinha, R. B.and Choudhary, K. 2003. Zinc research and agricultural production in Bihar.Technical Bulletin. Department of Soil Science, R. A. U., Pusa (Bihar).

Singh, B., Singh, M. and Dang, Y.P. 1987. Distribution of forms of zinc in some soils of Haryana. Journal of the Indian Society of Soil Science, 35: 217-224.

Singh, Y., Singh, B., Ladha, J. K., Khind, C. S., Gupta, R. K., Meelu, O. P. and Pasuquin, E. 2004. Long term effects of 
organic inputs on yield and soil fertility in rice-wheat rotation. Soil Sci. Soc. Amer. J., 68:845-53.

Smith, R.A., and Shoukry, K.S.M. 1968. Changes in distribution within three soils and zinc uptake by field beans caused by decomposing organic matter. "Isotopes and Radiation in soil organic matter studies". IAEA, Viena: 397-410.

Spalbar, I., Mondal A. K. and Rai A. P. 2017. Distribution of Zinc Fractions and Its Association with Soil Properties in Some Rice-Wheat Growing Soils of Jammu Region, India.
Int.J.Curr.Microbiol.App.Sci 6(4): 711721.

Umesh, U. N., Kumar, V., Prasad, R. K., Singh, K.D. N. and Singh, A. P. 2013. Integrated effect of fertilizers and organic manure on the forms of zinc and their availability under sugarcanebased cropping system in calciorthents. J. Indian Soc. Soil Sci. 61:371-74.

Viets, P.G., (Jr.) 1962. Chemistry and availability of micronutrients. Journal of Agriculture Food Chemistry. 10: 174178.

\section{How to cite this article:}

Sunil Kumar. 2017. Impact of Long-Term Green Manuring on Zinc Transformations in Calcareous Soil under Rice-Wheat System. Int.J.Curr.Microbiol.App.Sci. 6(9): 2883-2895. doi: https://doi.org/10.20546/ijcmas.2017.609.355 